\title{
The Impact of International Capital Flows on Jordan's Economic Growth
}

\author{
Basem M. Lozi* \\ Dept. of Finance Full Professor Al-Balqa Applied University, Jordan \\ Mamoun Shakatreh \\ Dept. of Finance Associate Professor Al-Balqa Applied University, Jordan
}

\begin{abstract}
The aim of this study is to examine the impact of international capital flows on the economic growth in Jordan during the period from 2005 to 2017, The study also examines trends and composition of capital inflows. The study used descriptive analytical research method which was appropriate for the purpose of research. By using time series data, the study found that Foreign Direct Investment (FDI), foreign portfolio investment (FPI), grants (Gr) and Worker remittances (WR) are positively affecting the economic growth direct contribution. Based on the research results, the study came with a several recommendations, the most important recommendation is; the government of Jordan should create and relax the rules and regulations to attract more investors, and also the government should work hand in hand with the developed countries to create economic and employment opportunities, improve the country's competitiveness, and expand growth within the private sector so that everyone in Jordan has the opportunity to contribute to a brighter future.
\end{abstract}

Keywords: International capital flow; Foreign direct investment; Worker remittances; Foreign portfolio investment; Economic growth; Jordan.

(9) (†) CC BY: Creative Commons Attribution License 4.0

\section{Introduction}

Foreign capital has played an important role in the economic development of many countries, which are presently considered developed economies. Most of less developed countries are still at stage where their development depends mainly on the flow of foreign capital in the form of grants, loans, and direct foreign investment. Countries with sound macroeconomic economic polices and well-functioning institutions are in the best position to reap the benefits of capital flows and minimize the risks.

Regardless of the fact that all the under developed countries need foreign capital flows for their development, the amount and the form of the foreign economics assistance differ from country to country. The country size and the economic circumstances of the country are the major determinants of the volume and the form of the foreign capital flows. For instance, the least developed countries of the Africa have been relying on the foreign aid, while the developing countries of the Asia are largest beneficiary of the foreign direct investment (FDI). In case of Jordan, the foreign capital inflow has a significant role in the country's economic development; the need of foreign capital inflows can be justified on the following ground: Firstly, the main argument is "Two- Gap Model", that is, deficits in BOP and deficit in savings is major argument in favor of foreign capital inflows. Secondly, the external assistance is also assumed to facilitate and accelerate because of the higher growth rates. Eventually, it is hoped that the need for the foreign capital inflows will disappear as local resources become able to make development self- sustaining.

\section{Review of Literature}

The past decades witnessed waves of financial globalization by a surge in international capital flows among industrial and developing countries. Such dense capital flows have been associated with high growth rates in some developing countries. The role of foreign economic assistance in economic development and growth remains contentions in economic literature, some studies proved its positive impact on the economic development empirically, while some studies highlighted its negative effects as well. As Momani (1991), "foreign capital inflow, consumption and economic growth, the experience of Jordan, 1968-1987", concluded, on the basis of empirical evidence from LCDs, that foreign capital inflows have positive effect on both consumption and investment. The results revealed that foreign capital was significant explanatory variable in both of the consumption and investment functions.

Hasan and Trap (2000), run a regression between aid and the growth. It is shown that aid increase the growth rate and this result aren't considered on good policy. There are, however, decreasing returns to aid, and the estimated effectiveness of aid is highly sensitive to the choice of estimator and the set of control variables, when investment and human capital are controlled for, no positive effect of aid is found. Yet, aid continues to impact on growth via investment.

Chigbu et al. (2015), examines the impact of capital inflows on economic growth of developing economies; the case of Nigeria, Ghana and India from 1986-2012. This is necessitated by the doubts being raised as whether the huge inflows of foreign capital in developing economies over the years have transmitted to real economic growth. 
Augmented Dickey Fuller unit root test was employed to evaluate the stationarity of the data, while Johansen Cointegration was used to estimate the long-run equilibrium relationship among the variables. The casual relationship was tested using Granger Causality, and Ordinary Least Square method was used to estimate the model. The findings reveal that capital inflows have significant impact on the economic growth of the three countries. In Nigeria and Ghana, foreign direct and portfolio investment as well as foreign borrowings have significant and positive impact on economic growth. Workers' remittances significantly and positively related to the economic growth of the three countries. The enabling environment should be created in the developing countries to encourage more inflow of foreign investments and workers remittances. This will help in closing the savings-investment gap and encourage economic growth in these countries. The study signifies that a capital inflow is indispensable in closing the savingsinvestment gap required for economic growth of developing countries.

Reham and Ahmad (2016), attempts to include all foreign capital inflow variables to analyze their impact on economic growth of 21 developing countries for the period of 1990 to 2013. Modern econometric techniques are applied for data analysis including panel unit root test and pooled mean group (PMG) estimation for short-run and long run analysis. The results indicate that inflows including net external debt and net official development assistance have significantly negative impact on economic growth of developing countries, while net foreign direct investment and net remittances have positive and significant impact on economic growth in the long-run. The negative sign of error correction term shows the convergence of the variables towards equilibrium in the long run. The study highlights the need of allocation of foreign resources effectively and efficiently.

Chorn and Seik (2017), attempts to examine the impact of foreign capital inflows which mainly consisting of foreign direct investment (FDI) and official development aid (ODA) on economic growth of developing countries. It is conducted to find out the one between the two forms of foreign capital inflows that has more effective and robust influence on the growth through the combination of the two catalysts into the same regression models. The study sample covers 77 developing countries from all regions classified by the World Bank from year 1997 to 2012. Ordinary Last Square (OLS) with time and entity fixed effects has been chosen as a method of running the regression, and robust function is used in regression in an attempt to control for the possible heteroscedasticity that often exists in panel data analysis. The results show that both FDI and ODA have positive and significant impacts on economic growth. Yet, FDI is seen to be more robust and statistically significant. Furthermore, the marginal impacts of FDI and ODA are not without constraint. The marginal impacts of both FDI and ODA on economic growth decrease given the rising level of initial income per head, treating other factors constant. Moreover, provided that its share of gross domestic saving increases the impact of ODA on growth would keep decreasing. The interaction term between FDI and gross domestic saving also has negative sign as portions of GDP, but the estimated coefficient is not statistically significant.

Phimmarong and Kinnalone (2017), examines the impact of different categories of foreign capital net inflows (FDI, Portfolio investment, and other investment) as well as domestic savings on economic growth in 6 ASEAN countries, namely Indonesia, Malaysia, Philippines, Singapore, and Thailand, and Lao PDR. Regression analyses based on Panel Fixed-Effects estimation, show that foreign capital inflows at aggregate level is negatively correlated with real GDP per capita growth rate. At disaggregate level, only FDI has significantly positive impact on real GDP per capita growth rate in the two periods while portfolio investment is not found to have any significant impact on growth in the studied periods. Short-term capital flows such as other investment is found to have negative impact on growth rate of real GDP per capita in the two sample periods, and its impact becomes statistically significant in the recent period, indicating the increase in its volatile nature. The results suggest that domestic savings should be effectively mobilized and channeled into productive investments. Besides, in the context of increasing global competition for FDI, developing countries should formulate policies to improve local skills and their human capital as to enhance the countries' absorptive capacity to reap benefit from FDI as well as to improve the quality of FDI that a country can attract.

Adam (2017), examines the effects of capital flows on economic growth in Senegal using autoregressive distributed lag (ARDL) over the period 1970-2014. Overall, our results show that remittances cause economic growth in Senegal in the long run. In contrast, external debt has a negative impact on economic growth. The ARDL results, however, show no cointegration between aid and growth or between foreign direct investment (FDI) and growth. The Quandt-Andrews breakpoint test selects year 1991 as the most likely breakpoint location for the remittances-growth equation. Finally, time-varying parameter analyses using the year 1991 as a slope dummy reveal that remittances have been growth-enhancing post-1991. Therefore, government and policy makers in Senegal must create a favorable atmosphere for attracting more remittances to promote economic development.

It concluded on the review of the above literature foreign capital has stimulated the economic growth on one hand and has substitution the domestic savings on the other hand. And it caused a severe debt serving problems in some countries. Accordingly, a foreign capital inflow has a positive impact on growth in other countries.

\subsection{Objectives of the Research}

The main objectives of this research are:

1. To propose a model to examine the impact of capital flows on economic growth.

2. To examine the trends and composition of capital flows.

3. To write a theoretical framework for the study variables in this research.

4. To provide some recommendations to the decision makers. 


\subsection{Date and Period of Study}

The secondary data involve both the qualitative and the quantitative data. There are three essential subgroups of secondary data: the survey data, the documentary data, and the multiple -source secondary data (Hasslinger et al., 2007). In this study, the researcher will concentrate on utlilzing the documentary sub-type of the secondary data such as: articles, books, internet and the previous studies that relate to the topic of the research.

The date for the study has been collected from the Central Bank of Jordan (CBJ) and Department of Statistics (DOS). The study attempts to investigate the effect of international capital inflow on Jordan's economic growth during the period 2005- 2017.

As soon as the data were collected, the responses were analyzed with the use of the descriptive statistics frequencies, means, percentages, and standard deviation. The Statistical Package of Social Science (SPSS) was used for analyzing the data. The data were entered into the program. Then, the initial analysis of the data is done, and then recommendations and conclusions were reached.

\subsection{Research Methodology}

An analytical, descriptive methodology approach was followed in this research as it is suitable to the objectives of the research. A systematic method for data analysis is implemented to investigate and explain the relationships and connections between the study variables. The research methodology field has been used to cover the practical side of this research, by answering questions, examining the validity of hypotheses of the study, and getting their results out of a data that was collected for the purposes of the study based on the steps of scientific norms.

\subsection{Model Design}

There have been few studies with different specification regarding the impact of foreign capital flows on Jordan's economic growth. In order to capture the relationship between the Foreign Direct Investment (FDI), Foreign Portfolio Investment(PFI), Worker Remittances (WR), and Grants (Gr.) the study tests stationary of the variables using different unit root tests, namely Dicky-fuller(DF), Dickey and Fuller (1981) and Phillips and Perron (1988) test.

Symbolically, the model on the impact of FDI, FPI, WR and Gr on Jordan's economic growth can be written as: $\mathrm{GDP}=\alpha 1 \mathrm{FDI}+\alpha 2 \mathrm{FPI}+\alpha 3 \mathrm{WR}+\alpha 4 \mathrm{Gr}$

Where:

GDP: gross domestic product

FDI: foreign direct investment.

FPI: foreign portfolio investment.

WR: Worker Remittances

Gr: Grants

$\alpha$ : Regression coefficients (to be estimated) measures how much units of GDP would changed with a unit change in independent variables (FDI, FPI, and WR).

\subsection{Research Hypothesis}

Ho1: There is no significant statistical impact of foreign direct investment on economic growth at the level of $(\alpha \leq 0.05)$ in Jordan.

Ho2: There is no significant statistical impact of foreign portfolio investment on economic growth at the level of $(\alpha \leq 0.05)$ in Jordan.

Ho3: There is no significant statistical impact of Worker Remittances on economic growth at the level of $(\alpha \leq 0.05)$ in Jordan.

Ho4: There is no significant statistical impact of Grants on economic growth at the level of $(\alpha \leq 0.05)$ in Jordan.

\section{Trends and Composition of Capital Flows into Jordan}

The Jordanian economy is dominated by tourism, financial services, transportation, manufacturing and remittances from Jordanians working abroad. Jordan's lack of arable land and insufficient supplies of water means that agriculture is mostly a non-relevant sector and that the country invests heavily in water recycling. Jordan's economy is highly influenced by the state, however, recently, the efforts have been undertaken to reduce barriers to do business. Jordan's economy expanded 1.8 percent year-on-year in the fourth quarter of 2018, compared to a 2 percent expansion in the prior period. It was the weakest growth rate since the last quarter of 2017, as output rose less for: manufacturing (1.2 percent from 1.9 percent in Q3); utilities (1.8 percent from 2.4 percent); restaurants \& hotels ( 0.7 percent from 0.9 percent); wholesale and retail trade (1.3 percent from 1.4 percent); and real estate (2.4 percent from 2.5 percent). In addition, mining \& quarrying fell 3.1 percent (from 2.1 percent in Q3) and construction activity shrank 0.3 percent (vs. -0.4 percent in Q3). In contrast, output increased further for transport, storage \& communications (3.6 percent from 2.8 percent); finance $\&$ insurance services ( 3.1 percent from 3.0 percent); and for agriculture, hunting, forestry \& fishing (3.1 percent from 2.9 percent). Considering 2018 as a whole, the economy grew 1.9 percent, slower than 2.1 percent in 2017. (Trading economics, 2019)

A principal source and stimulant of economic growth in Jordan has been the external financial resources that supplemented the gross domestic product and so helped finance levels of consumption and investment in both public and private sectors may above what could be sustained by domestic incomes. These external resources consisted partly of foreign direct investment, foreign portfolio investment and remittances of Jordanians. The said resources 
went instrumented to Jordan's impressive development record in past decades. However, side by side with the economic and social benefits that these resources have brought to Jordan, there has been concern for many years that external capital inflows are not a problem- free driver of the development process. The main features of their mixed impact are the following:

(a) The inflow of capital stimulates the economy by raising the levels of domestic expenditure and prices. It also bolsters the foreign exchange reserves and strengthens the exchange value of the national against foreign currencies.

(b) The expenditure effect takes place of the additional income generated by foreign transfers is spent on nontraded goods and services (education, health, welfare, construction and other services), while in the traded goods sector the rise in demand is easily met by imports. In comparative terms, local production of traded goals becomes relatively less profitable, resulting in discouragement of domestic production whether for import- substitution or for exports.

(c) Workers remittances, to the extent they supplement households incomes, tend to raise aggregative private consumption and family investment in education. To the extent they are directed to investment, they tend to favor investment that could be managed by remote control from another country, such as real state and building in contrast to investment in the more productive agricultural, industrial, and service projects that require the presence locally of the owner or stakeholder.

(d) Rising expenditure or real estate and building tends to raise land and property prices as well as the importance of rent and capital gain relative to wages and salaries, as a source of household income. Altogether, a significant proposition of the income of households thus originates remittances, property rents and capital gains rather than in wages and salaries arising from domestic productive employment.

Table-1. Capital flows into Jordan (2005 - 2017) JD. Million

\begin{tabular}{l|l|l|l|l|l}
\hline Year & GDP & FDI & FPI & WR & Gr \\
\hline 2005 & 7963.6 & 1257.8 & 221.7 & 1544.8 & 500.3 \\
\hline 2006 & 9362.8 & 2316.7 & -26.1 & 1782.7 & 304.3 \\
\hline 2007 & 10805.1 & 1859.1 & 595.8 & 2122.5 & 343.4 \\
\hline 2008 & 13971.2 & 2005.7 & 406.8 & 2242.0 & 718.2 \\
\hline 2009 & 15044.5 & 1713.3 & 447.0 & 2214.2 & 333.4 \\
\hline 2010 & 16417.2 & 1172.1 & 547.0 & 2247.3 & 401.7 \\
\hline 2011 & 17987.7 & 1046.2 & 208.5 & 2152.1 & 1215.0 \\
\hline 2012 & 19298.2 & 1063.1 & 326.8 & 2229.8 & 327.1 \\
\hline 2013 & 20981.4 & 1382.2 & 1172.5 & 2327.7 & 639.0 \\
\hline 2015 & 22365.9 & 1546.7 & 825.0 & 2388.0 & 1236.5 \\
\hline 2016 & 23475.7 & 1136.2 & 919.6 & 2423.3 & 886.2 \\
\hline 2017 & 24188.1 & 1102.6 & 845.9 & 2365.7 & 836.0 \\
\hline Source Depar & 25089.7 & 1182.0 & 676.7 & 3271.9 & 707.7 \\
\hline
\end{tabular}

Source: Department of Statistics, Annual statistical Bulletin, (various issues)

Historically, the Jordanian economy has benefited from massive investment by the Gulf countries, which continued to skyrocket until 2006. However, since then FDI has declined due to the international economic crisis, followed by geopolitical instability, andhave since remained stable. According to UNCTAD in 2018, FDI inflows totaled to USD 950 million, showing a decrease compared to last year (USD 2.0 billion). Estimated at USD 35 billion, the total stock of FDI represents $82.9 \%$ of the country's GDP. In order to boost FDI flows, the Government has planned large-scale infrastructure projects (water, transportation, nuclear energy) for which it needs foreign and private funds. A project linking the Dead Sea to the Red Sea was expected to start in 2018, but was postponed as Jordan could not reach an agreement with Israel on how to construct the canal. Nevertheless, the Israeli opposition seems to have dwindled and the Israeli government said early 2019 that it was ready to move ahead with the project. (UNCTAD's 2019 World Investment Report).

\section{Empirical Results}

This test has been used to ensure that there is no intervention between the three variables representing the independent variables before testing the research's hypotheses. The acceptable tolerance for the independent variable components that was less than (1) and more than (.01), the VIF that was less than (10) (Hair Jr., 1998). These results affirm that there is defenately no interference between the independent variable and point out that the research's model is good. All the skewness values are below $( \pm 1.00)$ which means the variables distribution is close to the normal distribution, thus meeting the assumption for mulipule and simple regression analysis.

Table-2. below shows Skewness, VIF and Tolerance for study variables

\begin{tabular}{l|l|l|l}
\hline Variables & Skewness & VIF & Tolerance \\
\hline Foreign direct investment & -0.722 & 1.546 & 0.666 \\
\hline Foreign portfolio investment & -0.447 & 1.658 & 0.572 \\
\hline Worker Remittances & -0.046 & 1.677 & 0.643 \\
\hline Gtants & -0.056 & 1.543 & 0.742 \\
\hline
\end{tabular}




\subsection{First Hypotheses}

H1: There is no significant statistical impact of foreign direct investment on economic growth at the level of $(\alpha \leq 0.05)$ in Jordan.

Table-3. Testing of first hypotheses

\begin{tabular}{l|l|l|l}
\hline (Constant) & Beta & T & Sig \\
\hline FDI & 11.815 & 4.514 & 0.001 \\
\hline R & 0.806 & & \\
\hline R square & 0.649 & \\
\hline F & 20.375 & \\
\hline Sig & 0.001 & \\
\hline
\end{tabular}

From the table (3) the F value shows the impact of the foreign direct investment on GDP, which indicated by (20.375) and its significance is $(0.001)$ which is less than $(\alpha \leq 0.05)$. This provides evidence to reject the hypothesis that states: "There is no significant statistical impact of foreign direct investment on economic growth at the level of $(\alpha \leq 0.05)$ in Jordan." and the alternative hypothesis is accepted.

The $\mathrm{R}$ value is (0.806) that means there is a positive relationship between the foreign direct investment and economic growth, the R Square for the hypothesis equals (0.649), which means the foreign portflio investment has explained $64 \%$ of the variance in the economic growth.

Based on the values of (beta) and (T) referred in table (2), we find that foreign direct investment value $(\mathrm{Beta}=11.815, \mathrm{~T}=4.514)$ where the significance as the value of $\mathrm{t}$ are less than $0.05(\alpha \leq 0.05)$ and have an impact on economic growth.

\subsection{Second Hypotheses}

H2: There is no significant statistical impact of foreign portfolio investment on economic growth at the level of $(\alpha \leq 0.05)$ in Jordan.

Table-4. Testing of second hypotheses

\begin{tabular}{l|l|l|l}
\hline (Constant) & Beta & T & Sig \\
\hline FPI & 12.185 & 4.578 & .007 \\
\hline R & 0.707 & & \\
\hline R square & 0.5 & & \\
\hline F & 10.989 & \\
\hline Sig & 0.007 & \\
\hline
\end{tabular}

From the table (4) the F value shows the impact of the foreign portfolio investment on GDP, which indicated by (10.989) and its significance is $(0.007)$ which is less than $(\alpha \leq 0.05)$. This provides evidence to reject the hypothesis that states: "There is no significant statistical impact of foreign portfolio investment on economic growth at the level of $(\alpha \leq 0.05)$ in Jordan." and the alternative hypothesis is accepted.

The $\mathrm{R}$ value is $(0.707)$ that means there is a positive relationship between the foreign portflio investment and economic growth, the $\mathrm{R}$ Square for the hypothesis equals $(0.5)$, which means the foreign portflio investment has explained $50 \%$ of the variance in the economic growth.

Based on the values of (beta) and (T) referred in table (3), we find that foreign potfolio investment value $(\mathrm{Beta}=12.185, \mathrm{~T}=4.578)$ where the significance as the value of $t$ are less than $0.05(\alpha \leq 0.05)$ and have an impact on economic growth.

\subsection{Third Hypotheses}

H3: There is no significant statistical impact of Worker Remittances on economic growth at the level of $(\alpha \leq 0.05)$ in Jordan.

Table-5. Testing of third hypotheses

\begin{tabular}{l|l|l|l}
\multicolumn{5}{c}{ Table-5. Testing of third hypotheses } \\
\hline Constant) & Beta & T & Sig \\
\hline WR & 3.373 & 2.504 & 0.029 \\
\hline R & 0.603 & & \\
\hline R square & 0.364 & & \\
\hline F & 6.293 & & \\
\hline Sig & 0.029 & & \\
\hline
\end{tabular}

From the table (5) the F value shows the impact of the foreign Worker Remittances on GDP, which indicated by (6.293) and its significance is (0.029) which is less than $(\alpha \leq 0.05)$. This provides evidence to reject the hypothesis that states: "There is no significant statistical impact of Worker Remittances on economic growth at the level of $(\alpha \leq 0.05)$ in Jordan." and the alternative hypothesis is accepted. 
The $\mathrm{R}$ value is (0.603) that means there is a positive relationship between the Worker Remittances and economic growth, the R Square for the hypothesis equals (0.364), which means the Worker Remittances has explained $36 \%$ of the variance in the economic growth.

Based on the values of (beta) and (T) referred in table (3), we find that Worker Remittances value (Beta=3.373, $\mathrm{T}=2.504)$ where the significance as the value of $\mathrm{t}$ are less than $0.05(\alpha \leq 0.05)$ and have an impact on economic growth.

\subsection{Fourth Hypotheses}

H4: There is no significant statistical impact of Grants on economic growth at the level of $(\alpha \leq 0.05)$ in Jordan.

Table-6. Testing of first hypotheses

\begin{tabular}{l|l|l|l}
\multicolumn{5}{|c}{ Table-6. Testing of first hypotheses } & T & Sig \\
\hline Constant) & Beta & 3.431 & 0.044 \\
\hline Gr. & 10.051 & & \\
\hline R & 0.566 & & \\
\hline R square & 0.32 & & \\
\hline F & 5.178 & & \\
\hline Sig & 0.044 & & \\
\hline
\end{tabular}

From the table (6) the F value shows the impact of the grants on GDP, which indicated by (5.178) and its significance is $(0.044)$ which is less than $(\alpha \leq 0.05)$. This provides evidence to reject the hypothesis that states: "There is no significant statistical impact of grants on economic growth at the level of $(\alpha \leq 0.05)$ in Jordan." and the alternative hypothesis is accepted.

The $\mathrm{R}$ value is (0.566) that means there is a positive relationship between the grants and economic growth, the $\mathrm{R}$ Square for the hypothesis equals (0.32), which means the grants has explained $32 \%$ of the variance in the economic growth.

Based on the values of (beta) and (T) referred in table (2), we find that foreign direct investment value $(B e t a=10.051, T=3.341)$ where the significance as the value of $t$ are less than $0.05(\alpha \leq 0.05)$ and have an impact on economic growth.

\section{Conclusion and Policy Implication}

International capital inflow positively affects economic growth, provided if utilized properly in developing countries above results shows that international capital inflow significantly enhances the performance of Jordanian economy (Metwally, 2004). However, worker remittances and grants contribute to the development only in the long run. Moreover, inflows in the form of foreign direct investment and foreign portfolio investment significantly effect if the political and business conditions are favorable in the host countries (Yousef, 2008). The objective of the research paper was to investigate the impact of foreign international capital inflows on economic growth of Jordan from the time period of 2005 to 2017.

The study tried to find the impact of international capital flows ( FDI, FPI, WR and Gr.) on economic growth of Jordan over the period of 2005 to 2017 , while using time series data. These results confirm a relation between variables and provide evidence in the support of GDP growth of Jordan.

Impacts of all these variables are found positive, FDI, FPI, WR and Gr. lead the Jordanian economy positively. Due to new policies adopted by the government investors are highly interested in investing to Jordan economy. According to time series data results Foreign Direct Investment has positive and significant impact on Jordan economy (Table 3 ). The $\mathrm{R}$ value is (0.806) that means there is a positive relationship between the foreign direct investment and economic growth, the $\mathrm{R}$ Square for the hypothesis equals (0.649), which means the foreign portflio investment has explained $64 \%$ of the variance in the economic growth. This is due direct linkage of FDI with the cash circulation in any economy. FDI came to Jordan especially in services sector which is the biggest sector of Jordan.

The analysis confirms the positive impact of foreign portfolio investment on economic growth (Table 4). The $\mathrm{R}$ value is $(0.707)$ that means there is a positive relationship between the foreign portflio investment and economic growth, the $\mathrm{R}$ Square for the hypothesis equals (0.5), which means the foreign portflio investment has explained $50 \%$ of the variance in the economic growth.The good and stable macroeconomic environment attracts foreign investors. In addition, foreign investors prefer to invest in the capital market which provides an opportunity of risk diversification. Jordan is one the middle east countries and always there is unstable political conditons in the region, however, still the government of jordan trying to relax the rules and regulations to attract more customers.

The analysis also confirms the positive impact of Remittance on economic growth (Table 5). The $\mathrm{R}$ value is (0.603) that means there is a positive relationship between the Worker Remittances and economic growth, the $R$ Square for the hypothesis equals (0.364), which means the Worker Remittances has explained 36\% of the variance in the economic growth. Remittances in Jordan used mainly for constructing new houses or investment in real estate in order to increase the welfare and the recipient household instead of investment in industrial sector.

However, grants impact on GDP growth in Jordan is found to be strongly positive. The R value is $(0.566)$ that means there is a positive relationship between the grants and economic growth, the $\mathrm{R}$ Square for the hypothesis equals (0.32), which means the grants has explained $32 \%$ of the variance in the economic growth. The economy grew steadily from 2008 to 2018 as the Government of Jordan promoted economic reform with social and political 
development. However, the global economic crisis and more recent regional instability have caused this progress to slow, adding significant economic pressure in a number of areas. Developed countries works with the Government of Jordan to create economic and employment opportunities, improve the country's competitiveness, and expand growth within the private sector so that everyone in Jordan has the opportunity to contribute to a brighter future.

\section{Recommendations}

Regional instability refers to political volatility in neighboring countries, which mainly hinders the economic growth of any country. The Middle East, for instance, has experienced long periods of civil war resulting in social, political and economic consequences for the countries involved. The effect of the Middle East conflict includes slowing the growth rate of GDP due to reduced productivity, increasing the Jordanian military expenditure at the expense of other vital lifelines, increased unemployment rates, reduced foreign income, intensified borrowing to fund budget deficits and taking severe measures, such as tax increases. Nothing good emanates from being a neighbor to an unstable country. Although the state had witnessed a global financial crisis, its recovery plan was coincidentally hindered by the regional instability occasioned by the Syrian conflict (Al-Shriedeh The Jordan Times, 2019).

1- The policy makers in Jordan should attract the capital inflow and take the advantages of the capital inflow spillover effects. Therefore, the government needs to improve its infrastructure facilities and relax the rules and regulations in order to attract more foreign investment.

2- Interest rates policy should be carefully designed to attract capital flows to official channels; policy makers should not only look at nominal interest rate should be adjusted to reflect inflationary pressures.

3- the research also strongly recommends that Jordan policy makers continue their efforts towards stabilizing the region because of its importance for Jordan development and progress.

4- Additionally, Jordan policy makers are recommended to diversify the economy to be an industrial instead of being a service based economy.

\section{References}

Adam (2017). The effects of capital on economic growth in Senegal. The Journal of Applied Economic Research, 11(2): 121-42.

Al-Shriedeh The Jordan Times (2019). Newspaper.

Chigbu, E. E., Ubah, C. P. and Chigbu, U. S. (2015). Impact of capital inflows on economic growth of developing countries. International Journal of Management Science and Business Administration, Inovatus Services Ltd, 1(7): 7-21.

Chorn and Seik (2017). The impact of foreign capital inflow on economic growth in developing countries. Journal of Finance and Economics, 5(3): 128-35.

Dickey and Fuller (1981). D.A. Dickey, W.A. FullerLikelihood ratio statistics for autoregressive time series with a unit root. Econometrica, 49(1981): 1057-72.

Hair Jr., J. F. (1998). Multivariate data analysis with readings. NJ Prentice-Hall: Englewood Cliffs.

Hasan and Trap (2000). Aid and growth regressions." Credit research paper. University of Nottingham.

Hasslinger, A., Hodzic, S. and Obazo, C. (2007). Consumer behaviour in online shopping. Kristianstaad University Department of Business Studies, Unpublished thesis.

Metwally (2004). Impact of EU- FDI on economic growth in middle eastern countries. European Research Studies, 7(1-2): 121-32.

Momani, R. (1991). Foreign capital inflow, consumption and economic growth: the experience of Jordan. Journal of King Saudi University, 1(2).

Phillips, P. C. B. and Perron, P. (1988). Testing for a unit root in time series regression. Biometrika, 75(2): $335-46$.

Phimmarong and Kinnalone (2017). The impact of foreign capital inflow on economic growth in 6 Asian countries. Ritsumeikan International Research, 30(1): 141-81.

Reham and Ahmad (2016). The impact of foreign capital inflow on economic growth: pooled mean group analysis for developing countries. Pakistan Economic and Social Review, 54(2): 191-203.

Yousef (2008). Economic evaluation of foreign direct investment in Pakistan. Pakistan Economic and Social Review, 46(1): 37-56. 